\title{
The Legality of Oil \& Gas Production Sharing Contract Gross Split Scheme
}

\author{
Fakharsyah Hanif Sugiyartomo ${ }^{1, *}$ \\ ${ }^{1}$ University of Indonesia \\ Received July $12^{\text {nd }}, 2018$; accepted February $27^{\text {th }}, 2019$ \\ Available online February $28^{\text {th }}, 2019$
}

\begin{abstract}
As an oil producing nation, Indonesia embodied its authority to manage its oil resources through article 33 paragraphs 3 of The Republic of Indonesia Constitution 1945. Regarding the article, this means that the state has the authority to manage Indonesian natural resources, directly or indirectly, through other public and/or private institutions and the profit of such activity shall be for the benefit of the people. This granted the state to appoint other institution, including a National/International Oil Company (NOC/IOC), to manage the exploration and production of oil, as that particular activity is regarded as a high risk and high capital business. In order to do so, according to Law no. 22 2001, the state may appoint a NOC/IOC through a production sharing contract. In this research, it is founded that the regulation that governed a production sharing contract with the gross split mechanism-Ministry of Energy and Mineral Resources Regulation No. 82017 jo. Ministry of Energy and Mineral Resources No. 52 2017-does not have a strong legal basis. In overall, the management of oil and gas through the gross split mechanism does not gives a maximum benefit for the state, and does not attract the IOC/NOC interest to explore and produce oil and gas in Indonesia. Therefore, in this paper, the reviewing of oil and gas management through a gross split mechanism is recommended.
\end{abstract}

Keywords: management, gross split scheme, income taxes

\section{Introduction}

Oil and gas industry is considered to be one of the most significant income for the state's finances, behind taxes. Oil and gas industry income has an inclining trend from 2009, with the contribution of 184,6 Trillion Rupiahs, to 320,3 Trillion Rupiahs in 2014. ${ }^{1}$ However, in 2015 there is a dramatic decline from the oil and gas industry income to only about 63,7 Trillion Rupiahs. This phenomenon is believed as an impact from the declining of oil price in the world. It is such a misfortune for Indonesia, as it has an enormous 3,7 Billion barrels of oil reserves, and Indonesia is considered as one of the twenty largest oil producing country. ${ }^{2}$

The dramatic decline of oil and gas income in the state's finance was caused by the declining investment in the oil and gas sector. Beside external factor mentioned above, Indonesia's oil and gas policy is not attracting enough for investor to produce in Indonesia. At least there are three factors that caused oil and gas investment has dropped in recent years; time consuming permits, unattractive fiscal policies, and criminalization towards contractors. First, in order to operate in Indonesia, contractors should have at least 6 permits from the Ministry of Energy and Mineral Resources, and another 44 from the Investment Coordinator Agency. ${ }^{3}$ Obtaining these permits also takes times to up to 15 years,

\footnotetext{
${ }^{1}$ http://iesr.or.id/wp-content/uploads/Heru-Wibowo_DJA-Kemenkeu.pdf

${ }^{2}$ BP Statistical Review of World Energy 2015.

${ }^{3}$ Ministry of EMR, Ministry of EMR Rules No. 29 2017, art.

* Corresponding author

E-mail address: hansugiyartomo@gmail.com
}

(C) 2019 PYC. All rights reserved. 
according to Executive Director of Indonesian Petroleum Association, Marjolijn Wong. In other countries, it only takes 3-5 years to obtain permits to produce oil and gas. ${ }^{4}$

Second, there is one rule that has been perceived as a problem in order to operate oil and gas in Indonesia: Government Rule No. 792010 (GR No. 79 2010). The GR No. 792010 erased "assume and discharge" mechanism in the oil and gas production sharing contract. Through "assume and discharge" mechanism, contractors are freed from indirect taxes, like importing taxes, value added tax, regional taxes, etc. ${ }^{5}$ However, with the issuance of GR No. 79 2010, contractors are obliged to assume indirect taxes as mentioned before as an operating cost, in which they has to be validated first by the Executive Agency of Oil \& Gas. Once the Executive Agency has validated the operating cost, contractors may receive a cost recovery for their reimbursement after producing a certain amount of oil and gas. The problem mostly occur when it comes to validating the operating cost, as contractors and Executive Agency have a different opinion regarding the number of taxes, and/or other operating costs. Hence, contractors will not start their production, until they reached an agreement with the Executive Agency about the operating cost, and this will endangering the availability of oil and gas for the people. The scarcity will then raising the price of gasoline and the domino effect shall continue to other commodities and needs.

Last but not least, criminalization also became another obstacle for contractors and investors alike to operate in Indonesia. This case happened in 2012 when Chevron Pacific Indonesia, Ltd was accused of corruption from its bioremediation program. The bioremediation program is a cleansing program of an oil-spilled soil through a biological organism. Chevron's bioremediation program - which considered as an operating cost that can be reimbursed through a cost recovery mechanism-was considered as fictive and causing state's loss. In fact, cost recovery was not considered as a state's finances, as it is separated from APBN (Anggaran Pengeluaran dan Belanja Negara), hence, there were no state's loss from this case. This is a trademark case that raises questions between contractors and scholars alike.

Given the negative effect of cost recovery mechanism as mentioned above, the Ministry of Energy and Mineral Resources has issued a new scheme of oil and gas production sharing contract through Ministry of Energy and Mineral Resources Rules No. 82017 (Ministry of EMR Rules No. 8 2017). With this new scheme, the split between contractors and the state is based on gross production made by the contractors, with initial/base split of $57 \%$ state $-43 \%$ contractors for oil, and $52 \%$ state $-48 \%$ contractors for gas. This initial/base split may changes according to variable and progressive split according to the exhibit in Ministry of EMR Rules No. 8 2017, or by any minister's discretion.

However, does this new scheme, regulated by a Ministry Rules, really what we needed to improve our investment rate in oil and gas industry? Unfortunately, this was not just the case, as this new scheme was considered just to be another obstacle to invest in oil and gas industry in Indonesia. There are some reasons why this new scheme is creating a new problem rather than fixing the existing ones. First, investors and contractors alike thought that a fluctuate split will make it hard for them to predict their net income and gain. Both variable and progressive split can only be negotiated after the characteristic of an oil reserve has been discovered, and it will surely makes contractors to render difficult in calculating their risk and their return. Second, a minister's discretion to adjust the split at any time will cause an uncertainty in the production sharing contract.

Aside from the technical problems as mentioned above, there is also a legal problem regarding the issuance of Ministry of EMR Rules No. 8 2017. According to Law No. 122011 that regulates the formation of legal rules, the hierarchy of positive legal rules is:

1. The Constitution of The Republic of Indonesia 1945 (UUD 1945);

2. The Decision of People Assembly (TAP MPR);

3. Legislative Rules/Act (UU);

\footnotetext{
${ }^{4}$ https://katadata.co.id/berita/2017/05/10/investor-sebut-dua-penyebab-rendahnya-investasi-migas-di-indonesia

${ }^{5}$ Ministry of Finance, Ministry of Finances Rules No. 177/PMK.011/2007, art 2 sec. 1.
} 
4. Government Rules (PP);

5. President Rules (Perpres);

6. Provincial Rules (Perda Provinsi); and

7. Municipal Rules (Perda Kabupaten/Kota)

A ministry rules, although did not explicitly mentioned in the hierarchy of positive legal rules, its existence is recognized and considered to have legal jurisdiction power, as long as its issuance is built upon a higher legal rules. ${ }^{6}$ This makes a ministry rules considered as the lowest legal rules compares to other legal rules, and its formation should always parallel with the legal rules above. Unfortunately, from any Legislative Rules to the Presidential Rules, there are no rules that regulating the issuance of a gross split scheme in oil and gas production sharing contract. In fact, through Government Rules No. 352004 (GR No. 35 2004), it is firmly said that contractors may receive a cost recovery from any cost related to the exploration and production of oil and gas. ${ }^{7}$

Given the introduction above, by this paper I intend to get a clearer sight of how an oil and gas industry be implemented in Indonesia through some questions below:

1. How does the oil and gas industry should be regulated in Indonesia?

2. How our positive law does regulate a clash between several legal rules that are different in terms of hierarchy, but regulate the same issue?

\section{Legal Aspect of Oil and Gas Industry}

When it comes to oil and gas regulation, Indonesia has gone a long way from implementing concession system - while under the Netherlands Colonial Government - to making a breakthrough as the first country to introduce the production sharing contract. Through the concession system, regulated under Indische Mijn Wet 1899, contractors are not only given the mining right, but also the right for the land itself. This system prevail until post-independence era, where in 1960, the government of The Republic of Indonesia has issued Law No. 441960 that regulated oil and gas mining. This change was applied based on the research conducted by the Chief of Commerce and Industry Chamber of the Indonesian Senate, Mr. Mohammad Hasan in 1951, which concluded: ${ }^{8}$

1) Oil fields in the North Sumatera should be nationalized to enhance national gain

2) The state does not take an optimal gain based on the concession system.

With the Law No. 441960 now prevail, the mining right has been diverted to the state-owned company, PT Permina-which later in the future merged with PT Pertamin to become PT Pertamina - and the state has sought to nationalized the companies that held a concession permit. NV Niam, a limited company, whose shares is owned by the state and Shell, is nationalized and renamed as PT Pertamin. Meanwhile, PT TMSU is also renamed as PT Permina. Other company that held the concession permit, like Shell, Caltex, and Stanvac, and cannot be nationalized has now become the contractors for the state-owned company. The state-owned companies are only given the mining right, without the right to the land itself, which differentiates Law No. 441960 to Indische Mijn Wet 1899. ${ }^{9}$ Therefore, in 1960, there are two state-owned company that held the mining right, and three companies that has become the state-owned company's contractors. These three companies became contractors through the Work Contract system, replacing the concession system.

\footnotetext{
${ }^{6}$ Indonesia, Law No. 12 2011, art. 7.

${ }^{7}$ Indonesia, Government Regulation No. 35 2004, art. 56 sec. 2.

${ }^{8}$ Adrian Sutedi, Hukum Pertambangan, (Jakarta: Sinar Grafika, 2011), pg. 51.

${ }^{9}$ H. Salim, Hukum Pertambangan di Indonesia, (Jakarta: RajaGrafindo Persada, 2005), pg. 263.
} 
The contractors enter their agreement with the state-owned companies, as the state's representative, through Tokyo Heads of Agreement, which has been signed in June, 1st 1963. Both parties are agreed as follows: ${ }^{10}$

1. The profits obtained from the operations carried out under the contract by the Companies shall be divided between the Government and the State Enterprise on the one hand and the Company on the other in the proportion of $60 \%$ to the former and $40 \%$ to the latter. The $60 \%$ due to the Government/State Enterprise shall include taxes under Indonesian fiscal law in dollars or sterling and in rupiah specially applicable and all exactions levied or to be levied, if any, by the Government or any other Authority in Indonesia except fees for services at rate generally applicable, taxes collected by the Company from others (such as personal income taxes of employees), and any duties on imports which are not to be used in the operations, or are for personal use or consumption of employees (other than machinery, equipment, tools, vehicles, aircraft, vessels, materials, medicines, ancillary supplies, and items of living equipment—excluding liquor and tobacco-which shall be reasonable and necessary in connection with the performance of operations under the contract);

2. None of the Companies shall be required to make any payment which would result in the Government receiving in total more than $60 \%$ as defined in above;

3. Each Company undertake to make available for the domestic fuel products requirements of Indonesia supplied from indigenous crude, and shall not exceed $25 \%$ of the total crude produced by the Company in Indonesia in such year.

The work contract regimes does not last long, as in 1964 it is replaced by the production sharing contract. This new concept of contract is first introduced by Ibnu Sutowo, the Minister of Mining and Oil and Gas, which has a basic substance as followed: ${ }^{11}$

1. The management control is held by the state-owned company;

2. The contract is based on the gain sharing;

3. Contractors shall bear the risk of pre-production, and if the oil was discovered, the cost recovery to the contractors shall not exceed $40 \%$ of the oil produced by the contractors;

4. The remaining $60 \%$ shall be split, with the state-owned company will receive $65 \%$, and $35 \%$ for the contractors;

5. Any tools and equipment purchased by the contractors shall belong to the state-owned company, once it has entered Indonesia, and the cost will be included in the $40 \%$ formula of cost recovery.

The production sharing contract, introduced first by Indonesia, considered as a breakthrough regarding the oil and gas industry in many countries in the world. In the 20th century, a concession system, mostly practiced by the colonial country, considered to be unfair, and giving contractors a large amount of rights in producing oil and gas. As a result, many countries in the world, especially the newly independent ones, are chasing a nationalized policy. Saudi Arabia, Iran, and Venezuela are focusing to develop their own national oil company and prohibit foreign oil company to undertake their business in their countries. The lack of experience and technical skills resulted in an unoptimized production, but in the other hand, those countries have no intention to loosen their authority through the concession system. ${ }^{12}$ The production sharing contract provides solutions regarding the problem mentioned, through its substance explained above.

\footnotetext{
${ }^{10}$ Cambridge University, "Indonesia and Caltex Pacific Oil Co., P.T. Shell Indonesia, and P.T. Stanvac Indonesia: Heads of Agreement for Petroleum Working Contracts", International Legal Materials Vol. 3 No. 1, (Januari 1964): 81.

${ }^{11}$ H. Salim, Op.Cit., pg. 266-267.

${ }^{12}$ Ingilab Ahmadov, et al., "How to Scrutinize a Production Sharing Agreement", International Institute for Environment and Development, (2012), hal. 21.
} 
In Indonesia, the production sharing contract is continued to be implemented with some changes and adjustments from time to time to accommodate economic and political situation. The first legal basis that regulates the implementation of production sharing contract in oil and gas industry is the Law No. 8 1971. That particular law, that also regulate the establishment of PT Pertamina as the state-owned company, says that PT Pertamina may conduct a cooperation with other parties regarding the provision of oil and gas through a production sharing contract. ${ }^{13}$ From time to time, the production sharing contract has evolved and is divided into generations, as follow: ${ }^{14}$

1. First generation of production sharing contract (1964-1977);

2. Second generation of production sharing contract (1978-1987);

3. Third generation of production sharing contract (1988-2002);

4. Fourth generation of production sharing contract (2002-2017).

With the issuance of Ministry of EMR Regulation No.8 2017, we can say that we have entered the fifth generation of production sharing contract, which are very different with its ancestors in the profit sharing mechanism.

The first generation of production sharing contract is characterized by these principles:

1. The management control is held by PT Pertamina;

2. Contractors shall provide any cost regarding the exploration and production of oil and gas;

3. The cost spent by the contractors regarding the production of oil and gas will be recovered with no more than $40 \%$ of production cost per year;

4. The remaining $60 \%$ will be split with the proportion of $65 \%$ for PT Pertamina, and $35 \%$ for the contractors;

5. The contractors shall pay their taxes to the government through PT Pertamina;

6. Contractors are obliged to provide the domestic needs of petroleum proportionally, with the maximum $25 \%$ of its oil share, at $0,2 \mathrm{USD} /$ barrel.

In 1978 and 1988, there are two major changes in the production sharing contract which resulted in the emergence of the second and third generation of oil and gas production sharing contract. The second generation started when The United States of America's government has issued the IRS Ruling, which considered that the "tax" given to the government through PT Pertamina is actually a "royalty". "Taxes", according to the IRS Ruling, are any deposit or payment directly to the government. There is also a "Generally Accepted Accounting Procedure" in which the limitation of the cost recovery to up to $40 \%$ is abolished..$^{15}$ In the third generation of production sharing contract, there is an alteration of the tax amount from $56 \%$ to $48 \%$. It is also in this generation that the First Tranche Petroleum ${ }^{16}$ mechanism is introduced, which gave the state the right to obtain $10 \%$ of crude oil production before the profit sharing. ${ }^{17}$

With the issuance of the Law No. 22 2001, along with it secondary rule, the Government Rule No. 35 2004 (GR No. 35 2005), the authority to represent the state to arrange production sharing contract has been diverted from PT Pertamina to the Executive Agency of Oil and Gas (BP Migas, which later changed to SKK Migas). ${ }^{18}$ Therefore, from this point on, PT Pertamina is only considered as an oil company, that may become a contractor to the state. The mining right is now held directly by the government through its representative, the Executive Agency of Oil and Gas. This law also divides oil and gas industry into upstream and downstream sector. The upstream sector consists of exploration and production, while the downstream sector consists of processing, transporting, storage, and commerce. ${ }^{19}$ The production sharing contract itself is conducted in the upstream sector.

\footnotetext{
${ }^{13}$ Indonesia, Law No. 81971 , art. 12.

${ }^{14}$ H. Salim, Op.Cit., pg. 272.

${ }^{15}$ Ibid, pg. 273.

${ }^{16}$ First Tranche Petroleum, according to GR No. 79 2010, is a particular amount of crude oil that may be received by the state and/or contractors per calendar year before the profit sharing and taxation occured.

${ }^{17}$ PWC, "Oil and Gas in Indonesia Investment and taxation Guide", Indonesia Oil \& Gas, (Agustus 2011): 43.

${ }^{18}$ Indonesia, GR No. 35 2004, art. 24 sec. 1.

${ }^{19}$ Indonesia, Law No. 22 2001, art. 5.
} 
It is in this generation that many problems regarding the oil and gas production sharing contract occurred. In the period of 2000-2005, the State's Financial and Development Supervisor (BPKP) reported that from 152 production sharing contract signed by the government, worth Rp 122,648 Trillion, there are some cost manipulation in the cost recovery system that caused the state loss to up to $\mathrm{Rp} 18,067$ Trillion. ${ }^{20}$ The contractors tend to mark up their production cost, so that in the end they may receive a higher amount of cost recovery. A cost recovery system, which initially aims to reimburse contractor's expense, has been manipulated as a modus operandi to obtain not only reimbursement, but also an additional gain by the contractors. Below is the table that shows the detail of cost recovery manipulation practiced by the contractors

Table 2.1. Cost Recovery Manipulation 2000-2005

\begin{tabular}{|r|l|r|}
\hline No. & \multicolumn{1}{|c|}{ Description } & \multicolumn{1}{|c|}{ Amount (in Million Rupiah) } \\
\hline 1 & Income Tax & 6.242 .643 \\
\hline 2 & Credit Investment & 2.476 .859 \\
\hline 3 & Home Office Cost & 1.626 .175 \\
\hline 4 & Tax Allowance & 860.240 \\
\hline 5 & Unauthorized Foreign Worker's Wage & 495.708 \\
\hline 6 & Unapproved Cost by The Executive Agency & 470.641 \\
\hline 7 & Asset Depreciation and Overlifting & 462.933 \\
\hline 8 & Unauthorized Procurement & 409.901 \\
\hline 9 & Unrelated Cost to Prodcution Sharing Contract & 204.913 \\
\hline 10 & Legal/Consultant/Audit Fee & 163.621 \\
\hline
\end{tabular}

Given the fact above, the government is now intended to set up a tighter policy regulating the cost recovery in production sharing contract. Thus, the GR No 792010 was born. However, the question is, does this new regulation is keeping the investors and contractors alike while preventing any manipulation regarding the cost recovery system? For the first four year, it looks like that the GR No 792010 was considered as a breakthrough where the income from the oil and gas industry is showing a positive trend, with its peak income reach out to Rp 320,3 Trillion which occurred in 2014. This shows that the state has succeed to maintain the investors and contractors to do their business in the oil and gas industry, and has optimized the income by minimize, if not eradicate, any manipulation that may occur.

GR No. 792010 has classified operation cost that may be recovered using cost recovery mechanism, which consists of: ${ }^{21}$
a. Exploration cost
b. Production cost
c. Other cost

Exploration cost consists of (i) drilling cost, which consists of exploration drill and development drill, (ii) geological and geophysical research, (iii) general and administration cost, and (iv) depreciation cost. Prodcution cost consists of (i) direct cost for producing oil and gas, (ii) processing cost, (iii) utility cost, (iv) general and administration cost, and (v) depreciation cost. Meanwhile, other cost consists of any expenses in transporting gas, and any expenses occurred in post-upstream industry. Those cost needs to be validated first by the Executive Agency for contractors to gain their cost recovery.

Still, another problem arise when the oil price has dropped dramatically in 2015 due to energy revolution where countries in Europe and North America converted from using oil and gas to

\footnotetext{
${ }^{20} \mathrm{http} / /$ www.hukumonline.com/berita/baca/hol16094/bpkp--ada-indikasi-penyimpangan-icost-recoveryisebesar-18-trilliun

${ }^{21}$ Indonesia, GR No. 79 2010, art. 11.
} 
renewable energy, and efficiency in petroleum usage. ${ }^{22}$ On the other hand, oil producing countries are maintaining their production, and thus there is a climb on supply when the demand is low that lowering the oil price. This sole phenomenon would make a heavy damage in oil and gas industry, and it could be worsened with an unattractive fiscal policy-which unfortunately did happen in Indonesia.

The negative side from GR No. 792010 is that it is imposing indirect taxes like importing tax; value added tax; and regional tax as an operating cost. ${ }^{23}$ The consequences is, those taxes must be validated first by the Executive Agency in order to obtain the cost recovery. The problem mostly occur when it comes to validating the operating cost, as contractors and Executive Agency have a different opinion regarding the number of taxes, and/or other operating costs. Hence, contractors will not start their production, until they reached an agreement with the Executive Agency about the operating cost, including taxes, and this will endangering the availability of oil and gas for the people.

\section{Issues Regarding the Gross Split Mechanism}

Realizing that the cost recovery mechanism regulated by the GR No. 792010 does not favor investors and contractors alike in their business, and therefore threatening the availability of oil and gas supplies if they walk away, the government has issued the Ministry of EMR Regulation No. 82017 jo. Ministry of EMR Regulation No. 52 2017. This regulation introduce a new mechanism in oil and gas production sharing contract, called a gross split sliding scale mechanism. With the gross split mechanism, contractors and the state shall divide their oil and gas based on gross production, once oil has been discovered in a particular economical amount with the percentage of $57 \%$ for the state and $43 \%$ for contractors. This initial split between the state and contractors is called as the "base split". The base split may vary at any time regarding to the "variable component" and "progressive component". So, the final split that may be received by the state and contractors is not permanent, and may constantly be adjusted regarding the progressive and variable component. The list of variable and progressive component can be found in the exhibit of Ministry of EMR Regulation No. 52 2017, which consist of:

Variable component, consist of:

1. Working area status (may increase the contractors split to $0-5 \%$ );

2. Site location (may increase the contractors split to $0-16 \%$ );

3. Reservoir depth (may increase the contractors split to $0-1 \%$ );

4. The availability of infrastructure (may increase the contractors split to 0-4\%);

5. Reservoir type (may increase the contractors split to $0-16 \%$ );

6. Carbon dioxide content (may increase the contractors split to 0-4\%);

7. Hydrogen sulfide content (may increase the contractors split to 0-4\%);

8. Oil density (may increase the contractors split to $0-1 \%$ );

9. Domestic component level (may increase the contractors split to 2-4\%); and

10. Production stages (may increase the contractors split to $0-6 \%$ )

Progressive component, consist of:

1. Oil price (the split adjustment is determined by the domestic oil price in Indonesia, set by the minister);

2. Natural gas price;

3. Cumulative production of oil and gas (may increase the contractors split to $0-10 \%$ )

At least there are three objectives aimed by the government with the issuance of this gross split mechanism. First, the government intended to encourage the effectiveness and efficiency of oil and gas industry. With the cost recovery mechanism, there are so many clauses and provisions that require to be validated by the Executive Agency. At this stage, as mention earlier, both parties (Executive

\footnotetext{
${ }^{22}$ https://finance.detik.com/market-research/d-3443300/3-alasan-harga-minyak-dunia-turun

${ }^{23}$ Indonesia, GR No. 79 2010, art. 11, sec. 4 (f).
} 
Agency and contractors) has some different opinion regarding a clause, and this has proven to detaining the signing of production sharing contract. Second, the government aim to encourage the contractors to be more efficient in managing the cost and risk of producing oil. Therefore, every risk and cost shall be bear to contractor's expense. Third, to encourage the business aspect of production sharing contract to be simpler and more accountable, without any debate and manipulation regarding the cost recovery fund.

Unfortunately, rather than giving solution by attracting investors and contractors alike, this new split mechanism is giving another problem, as practically, it is worse than the cost recovery mechanism. From the contractors' point of view, there are some reasons that show us why the gross split mechanism is lowering the investment in oil and gas in Indonesia. First, there is an uncertainty in calculating risk. This was caused by the changing split, as an impact of adjustment based on variable and progressive component. Secondly, the incentive offered by the variable and progressive component itself, is not attractive enough to maintain the contractors as it is considered to be far below from the profit projected by the contractors. Last, the continuation of the producing activity is also threatened if the contractors are bearing the expenses alone. If contractors were pushed to be more efficient in managing cost and risk of producing activity, the best option for them is by pressing down their operating cost, by downgrading their equipment and facilities to the cheapest one, with lesser qualities. Changing the quality of the fundamental equipment or facilities shall affect the quantity of oil gained from production. In longer terms, the inferior equipment and facilities also have a shorter period of usage, while in the other hand, the producing activity is considered as a lengthy business.

Aside from its practical issues, the gross split mechanism is also facing a legal issue, as it does not have a strong legal basis, in which it is only regulated in a ministry regulation. A ministry regulation is considered as the lowest regulation, which needs a delegate authority from a higher regulation, in order to gain a juridical power and considered to be valid. Therefore, the substance of a ministry regulation should be aligned with its higher regulation-which could be a legislative rule, a government rules, or a presidential rules. Problem is, there are no higher rules, than the ministry rules, that ordered or regulated a production sharing contract using a gross split mechanism. In fact, GR No. 352004 that regulated the upstream activity of oil and gas allows contractors to receive a sum of recovery for any cost they have expended in the exploration and production activity. Thus, the gross split mechanism regulated by the Ministry of EMR Rules No. 82017 jo. Ministry of EMR Rules No. 52 2017, is contradict with its higher regulation, the GR No. 35 2004, where it has prohibited a cost recovery for contractors.

\section{Hierarchy of Legal Norms}

In his stufentheorie, Hans Kelsen said that legal norms are layered and graded in a particular structure of hierarchy. It means that a lower legal norms are based on a higher legal norms, and so on to a level in which the highest norm - a grundnorm - is founded. Therefore, law is always formed and/or erased based on a higher legal norm, so that in the end, law is graded and layered in a particular order, forming a particular hierarchy. A legal norm possessed its validity in a way that has been determined by another legal norm, and the latter has become a legal basis for the establishment of the former. Kelsen's stufentheorie itself has been adopted in Indonesia, through Law No. 12 2011, in which one of the principles of forming regulation is "the congeniality of type, hierarchy, and substances". Ths law also regulate the type and hierarchy of regulations, starting from the Republic of Indonesia Constitution 1945 in the top, to the municipal regulation in the bottom.

According to Kelsen's theory above, which also has been implemented in Indonesian law, the formation of Ministry of EMR Regulation No. 82017 jo. Ministry of EMR Regulation No. 522017 is violating the principles of regulation forming. Then, what is the legal impact of this matter? According to Law No. 12 2011, if there are any regulation below the legislative rule, that are contradict with the latter; the former may be submitted to the Supreme Court for a judicial review. It means that a regulation cannot be considered as null and void, but it is voidable using a praticular 
legal mechanism. This is based on the principle that a legal norm is always valid and have a judicial power, and therefore cannot be null and void, but it is voidable.

\section{Conclusion}

Based on the explanation above, we can conclude that the cost recovery mechanism is still considered to be a better option than the gross split, both from legal and practical perspectives. From this paper, I suggest that oil and gas production sharing contract should be implemented with the cost recovery mechanism and also adopting the assume and discharge mechanism. This will attract investors as they will have two incentives: freed from indirect taxes, and gaining a repayment from their production cost. As for the state, the cost recovery mechanism also ensure the amount of its split, as the cost recovery mechanism have a more rigid split system, compared with the gross split mechanism.

If the government is insisting to implement the gross split mechanism, regardless its practical issues, they have to immediately establishing a higher regulation that accommodate the gross split mechanism in production sharing contract. As mentioned above, even though the Ministry of EMR No. 82017 jo. Ministry of EMR No. 522017 does not automatically null and void for its contradiction with the higher regulation; it really has no strong legal basis, and thus is vulnerable to be void if submitted to the Supreme Court for a judicial review.

\section{References}

Ahmadov, Ingilab. et al. "How to Scrutinize a Production Sharing Agreement". International Institute for Environment and Development. (2012): 21.

Cambridge University. "Indonesia and Caltex Pacific Oil Co., P.T. Shell Indonesia, and P.T. Stanvac Indonesia: Heads of Agreement for Petroleum Working Contracts". International Legal Materials Vol. 3 No. 1. (January 1964): 85.

http://iesr.or.id/wp-content/uploads/Heru-Wibowo_DJA-Kemenkeu.pdf

https://katadata.co.id/berita/2017/05/10/investor-sebut-dua-penyebab-rendahnya-investasi-migas-diindonesia

http://www.hukumonline.com/berita/baca/hol16094/bpkp--ada-indikasi-penyimpangan-icostrecoveryi-sebesar-18-trilliun

https://finance.detik.com/market-research/d-3443300/3-alasan-harga-minyak-dunia-turun

Indonesia (a). Law No. 22 Year 2001. LN No. 136 Year 2001. TLN No. 4152.

Indonesia (b), Law No. 12 2011, LN No 82 Year 2011, TLN No. 5234

Indonesia (c). Government Regulation No. 79 2010. LN No. 139 Year 2010. TLN No. 5173.

Indonesia (d). Government Regulation No. 35 2004. LN No. 123 Year 2004. TLN No. 4435.

Indrati, Maria Farida. Ilmu Perundang-Undangan (1) (Jenis, Fungsi, Materi Muatan) cet. ke-1. Yogyakarta: Penerbit Kanisius. 2007.

Kelsen, Hans. General Theory of Law and State, cet.ke-6. Massachusetts: Cambridge University Press. 2003.

Ministry of Energy and Mineral Resources. Ministry of EMR Resources No. 8 Year 2017.

PWC. "Oil and Gas in Indonesia Investment and taxation Guide". Indonesia Oil \& Gas. (August 2011): 43.

Salim, H. Hukum Pertambangan di Indonesia, Jakarta: RajaGrafindo Persada. 2005.

Sutedi, Adrian. Hukum Pertambangan. Jakarta: Sinar Grafika. 2011.

Syamsuddi, Azis. Proses Dan Teknik Penyusunan Undang-Undang. Jakarta: Sinar Grafika. 2011. 